\title{
PENGARUH ENTREPRENEURIAL ORIENTATION, CULTURE ORGANIZATION INTERNAL FACTOR TERHADAP PERFORMANCE ORGANIZATION MELALUI CORPORATE ENTREPRENUERSHIP CAPABILITY PADA UMKM BATIK TULIS DI JAWA TIMUR
}

\author{
Chandra Kartika ${ }^{1}$ \\ * Program Manajemen Pemasaran, Fakultas Ekonomi, Universitas Wijaya Putra \\ *chandrakartika@uwp.ac.id ${ }^{l}$ \\ Soenarmi ${ }^{2}$ \\ * Program Manajemen Pemasaran, Fakultas Ekonomi, Universitas Wijaya Putra \\ *soenarmi@uwp.ac.id ${ }^{2}$
}

\begin{abstract}
Abstrak
Penelitian ini bertujuan untuk memberikan perubahan paradigma pembisnis agar dapat mengembangkan bisnis yang di kelola dengan baik dengan menggunakan beberapa variabel entrepreneurial orientation, culture organization, internal factor dalam meningkatkan permormance organization yang melalui corporate entrepreneur capability dan dapat meningkatkan tingkat kesejahtaraan dengan pengembangan karakter kewirausahaan pada seluruh masyarakat UMKM Batik Tulis di Jawa timur. Peneliti berusaha membantu untuk menyelesaikan permasalahan yang perekonomian yang masih belum optimal pada masyarakat UMKM Batik Tulis Di Jawa Timur dan dalam peningkatan ekonomi kreatif yang bersinergi dalam meningkatkan kinierja bisnis dalam suatu organisasi UMKM Batik Tulis di Jatim, sehingga tingkat pendapatan UMKM Batik Tulis di masayarakat sekitar Jawa timur dapat meningkat pula. Peneliti mengambil sampel sekitar 100 orang pengusaha yang memiliki Usaha UMKM Batik di Jawa Timu dan menggunakan metode analisis kuantitatif serta menggunakan alat analisa SEM AMOUS dan lokasi sudah ditentukan di peneliti, dari suatu temuan diharapkan untuk ditemukan hasil yang positif terhadap perkembangan bisnis UMKM Batik Tulis tersebut dan dapat membantu tingkat profit penjualan dan dapat memperbaiki tingkat teknologi yang digunakan oleh pengusaha serta meningkatkan tingkat kesejahteraan masyarakat UMKM Batik Jatim. Dan dapat meningkatkan Kinerja pada organisasi UMKM Batik Tulis di Jawa Timur.
\end{abstract}

Keywords: entrepreneurial orientation, culture organization, internal factor, permormance Organization, corporate entrepreneur capability

\section{Pendahuluan}

Usaha Mikro Kecil Menengah (UMKM) sebagai salah satu pelaku kegiatan ekonomi secara langsung maupun tidak langsung ikut dipengaruhi gejolak negatif perekonomian ini. Hasil riset Bank Indonesia (BI, 2001), menjelaskan bahwa sepanjang krisis ekonomi ternyata hanya 4\% UMKM yang mengalami kebangkrutan, $31 \%$ lainnya harus mengurangi skala usahanya dan sisanya sebanyak $64 \%$ tidak mengalami perubahan berarti dalam kinerja usahanya. Kenyataan ini berlawanan dengan usahausaha besar yang mengalami kemunduran usaha. Disamping ketahanan bisnis yang cukup

Riset Akuntansi dan Keuangan Indonesia, 2(1), 2017 mengagumkan, sektor UMKM yang selama ini juga tidak terlalu diperhitungkan keberadaannya ternyata memiliki peran ekonomi yang cukup strategis seperti misal dalam hal penyerapan tenaga kerja Isa, (2007). Survei menunjukkan bahwa sektor UMKM mampu menyerap 64,3 juta tenaga kerja (BI, 2001). Sehingga tidak dapat di ingkari betapa pentingnya UMKM. Selain itu, selama ini UMKM juga berperan sebagai suatu motor penggerak yang sangat krusial bagi pembangunan ekonomi dan komunitas lokal.

Fenomenal Saat ini, UMKM memiliki peranan baru yang lebih penting lagi yakni sebagai salah satu faktor utama pendorong perkembangan dan pertumbuhan ekspor non migas dan sebagai industri 
pendukung yang membuat komponen-komponen untuk industri besar lewat keterkaitan produksi Tambunan,(2001). Mengingat peran pentingnya UMKM bagi sosial ekonomi Indonesia, menurut Pahlevi (2006), dalam kurun waktu Tahun 2009-2015 Pemerintah mentargetkan mencetak sebanyak enam juta wirausaha baru. Langkah-langkah yang ditempuh untuk mencapai target tersebut adalah melalui 3 jalur yang meliputi: (1) jalur pendidikan, (2) jalur pengusaha, dan (3) jalur kelompok pembina. Melalui jalur pendidikan, total wirausaha baru ditargetkan per Tahun yaitu 917.840 orang, maka selama 5 Tahun sebanyak 4.623.400 orang. Melalui jalur pengusaha sebanyak 278.320 orang, maka selama 5 Tahun 1.308.600 orang. Jalur kelompok pembina, total wirausaha yang ditargetkan adalah 14.000 orang, maka selama 5 Tahun sebanyak 68.000 orang. Total target di seluruh Indonesia per Tahun dapat mencetak wirausaha baru sebanyak 1.209 .760 orang. Sasaran penumbuhan wirausaha baru tersebut dibagi berdasarkan sektor usaha, yaitu sektor industri $69 \%$, sektor perdagangan $19 \%$ dan sektor jasa $12 \%$. Sedangkan, berdasarkan skala usaha wirausaha target penumbuhan wirausaha baru dapat dikelompokkan menjadi menengah, kecil dan mikro Pahlevi, (2006). Pencetakan wirausaha baru dan pengembangan jiwa kewirauasahaan bagi UMKM sangat penting dilakukan mengingat masih seringnya ditemukan banyak UMKM yang tidak bisa bertahan hidup, dan kontribusi UMKM terhadap Pendapatan Daerah Bruto (PDB) yang belum setara dengah jumlah unit usaha dan jumlah tenaga kerja yang ada. Hal ini diduga karena banyak pelaku UMKM yang belum memiliki jiwa kewirausahaan dan banyaknya UMKM yang dijadikan sebagai pekerjaan sampingan, selain menjadi Pegawai Negeri Sipil (PNS) dan pegawai swasta lainnya Isa, (2007).

Penelitian Thomas and Mueller, (2000) menyebutkan kewirausahaan merupakan sikap dan perilaku wirausaha. Wirausaha ialah orang yang inovatif, antisipatif, inisiatif, pengambil risiko dan berorientasi laba. Ini berarti kewirausahaan merupakan sikap dan perilaku orang yang inovatif, antisipatif, inisiatif, pengambil risiko dan berorientasi laba. Menurut Shane and Venkateraman, (2000) menjelaskan bahwa kewirausahaan merupakan suatu proses melakukan sesuatu yang baru dan berbeda dengan tujuan menciptakan kesejah- teraan bagi individu dan memberi nilai tambah pada masyarakat. Berkaitan dengan itu, (Pinchot, 1985; Kuratko et al.,
1990; Luchsinger and Bagby, 1987; Carrier, 1996; Antoncic and Hisrich 2001, 2003) menerangkan bahwa istilah kewirausahaan berasal dari entrepreneurship, yang diartikan 'the backbone of economy', yaitu syaraf pusat perekonomian atau 'tailbone of economy', yaitu pengendali perekonomian suatu bangsa. Secara etimologi, kewirausahaan merupakan nilai yang diperlukan untuk memulai suatu usaha atau suatu proses dalam mengerjakan suatu yang baru dan sesuatu yang berbeda Katz, (2003).

Research gap yang terjadi pada penelitian sebelumnya (1) Borch (2004) menyimpulkan kapabilitas kewirausahaan berpengaruh positif dan signifikan terhadap orientasi kewirausahaan, (2) Li, Zhao, Tan dan Liu Yu (2001) menjelaskan orientasi kewirausahaan moderasi dengan teori hubungan antara orientasi pasar, orientasi kewirausahaan dan kinerja perusahaan pada usaha kecil di Cina, (3) Poon, June, Ainudin, Raja, dan Junit, Sa'Odah (2006) menjelaskan orentasi kewirausahaan sebagai mediator hubungan efektifitas konsep diri dan kinerja perusahaan, (4) Brown (1996) menjelaskan orentasi kewirausahaan memiliki pengaruh positif dan signifikan terhadap peningkatan kinerja perusahaan, dan (5) Davidsson, (1998) menjelaskan orentasi kewirausahaan secara signifikan berpengaruh untuk meningkatkan kinerja perusahaan.

Research Gap yang terjadi pada Orientasi kewirausahaan cenderung memiliki implikasi positif terhadap kinerja perusahaan. Hasil penelitian terdahulu Wiklund dan Shepherd (2005) mengidentifikasi hubungan positif antara orientasi kewirausahaan dan kinerja bisnis, demikian juga Wiklund (1999). Akan tetapi penelitian Frank et al., (2010) orientasi kewirausahaan berpengaruh negatif terhadap kinerja bisnis. Demikian juga penelitian terdahulu menunjukan lemahnya hubungan antara orientasi kewirausahaan dengan kinerja perusahaan (Lumpkin dan Dess, 2001). Adanya gap tersebut membuat peneliti tertarik untuk meneliti kembali hubungan orientasi kewirausahaan dengan kinerja perusahaan. Menurut Zahra 1993; Dess, Lumpkin \& McGee 1999; Bouchard 2001). Agar perusahaan mendapatkan keuntungan atas penerapan strategi, harus melalui corporate entrepreneurial Capability Sehingga orientasi kewirausahaan dalam penelitian ini selain secara langsung terhadap kinerja juga diprediksi mempengaruhi kinerja melalui corporate entrepreneur Capability. 
Penelitian ini dilakukan dengan pengembangan teori pertama yang dipakai dalam mendukung penelitian ini adalah Resource Based Advanted Theory karena merupakan teori umum dalam bidang pemasaran berguna untuk memahami dan mempridiksi semua fenomenal pemasaran sehingga berlaku secara umum dan memiliki ranah dengan jangkauannya yang luas dibandingkan teori-teori lainnya, menurut Conner, (1990) mengatakan bahwa Resource Advantege Theory merupakan teori yang mengungkapkan mengenai heterogenitas kompetensi dan kapabilitas yang dimiliki oleh suatu perusahaan. Kompetensi didalam RBV ditekankan pada resource seperti plant, equipment, land, material sebagai resource fisik, labor, managerial staff, engineers sebagai sumberdaya manusia. Akan tetapi, RBV ini adalah teori yang mengembangkan internal kompetensi dari perusahaan tersebut tanpa memikirkan bagaimana perkembangan lingkungan luar yang pada saat ini dalam kondisi yang turbulence.

Penelitian ini juga menggunakan pendekatan sebuah teori Theory of Planned Behavior didasarkan pada asumsi bahwa manusia adalah makhluk yang rasional dan menggunakan informasi-informasi yang mungkin baginya, secara sistematis. Orang memikirkan implikasi dari tindakan mereka sebelum mereka memutuskan untuk melakukan atau tidak melakukan perilaku-perilaku tertentu. Teori ini menyediakan suatu kerangka untuk mempelajari sikap terhadap perilaku. Berdasarkan teori tersebut, penentu terpenting perilaku seseorang adalah intensi untuk berperilaku. Intensi individu untuk menampilkan suatu perilaku adalah kombinasi dari sikap untuk menampilkan perilaku tersebut dan norma subjektif. Sikap individu terhadap perilaku meliputi kepercayaan mengenai suatu perilaku, evaluasi terhadap hasil perilaku, norma subjektif, kepercayaan-kepercayaan normatif dan motivasi untuk patuh.

Menurut Robert W. Duncan (2007, 142), menganalisa lingkungan internal dan eksternal merupakan hal penting dalam proses perencanaan strategi. Faktor-faktor lingkungan eksternal didalam perusahaan biasanya dapat digolongkan sebagai Strength (S) atau Weakness(W), dan lingkungan eksternal perusahaan dapat diklasifikasikan sebagai Opportunities $(\mathrm{O})$ atau Threat $(\mathrm{T})$. Analisis lingkungan strategi ini disebut sebagai analisis SWOT. Penentuan posisi perusahaan sangat penting bagi perusahaan dalam memiliki alternatif strategi untuk menghadapi perubahan yang terjadi dalam usaha yang dijalankan. Karyawan, pemerintah, investor dan banyak orang lain mendapatkan keuntungan ekonomi dari kegiatan kami. Sebuah kesempatan yang berkembang adalah untuk memenuhi kebutuhan konsumen berpenghasilan rendah dalam mengembangkan dan pasar negara berkembang. Apakah itu melalui saluran distribusi baru, menggunakan. Selanjutnya menurut Kanter, 1985; Hisrich and Peters, 1986; Brazeal, 1993 yang mengidentifikasi faktor internal sebagai segala sesuatu yang berada di luar batas organisasi. Secara garis besar sebuah perusahaan akan dipengaruhi oleh lingkungan perusahaan dimana lingkungan tersebut dapat dibagi kedalam dua bagian besar, yaitu lingkungan eksternal dan lingkungan internal. Faktor internal mencakup kekuatan dan kelemahan di dalam internal perusahaan itu sendiri. Penyusunan strategi perusahaan yang tepat harus memperhatikan betul-betul apa kekuatan dan kelemahan yang dimilikinya selain memperhatikan faktor eksternal. Damanpour (1991) menjelaskan bahwa Corporate Entrepreneurship Capability merupakan kemampuan yang fokus pada memberi tenaga kembali dan mempertinggi kemampuan organisasi untuk mendapatkan keahlian dan kapabilitas inovasi. Sebuah inovasi dapat berupa produk dan pelayanan baru, sebuah sistem administratif atau perencanaan baru atau program baru yang bersinggungan dengan anggota organisasi. Morris, Kuratko dan Covin (2008:11) menjelaskan bahwa Corporate Entrepreneurship Capability adalah istilah yang dipergunakan untuk mendeskripsikan kemampuan perilaku entrepreneurial di dalam organisasi skala menengah dan besar yang telah mapan. Konsep Corporate Entrepreneurship Capability walaupun sudah dikembangkan dengan baik oleh Antoncic (2004) dan Zahra (2000), tetapi secara spesifik anteseden Corporate Entrepreneurship Capability belum dikaji secara dalam. Penekanan pada proses Corporate Entrepreneurship Capability dipandang sebagai kunci keberhasilan perusahaan dalam peningkatan kapabilitas agar memiliki nilai kompetitif (Fitzgerald E M, 2002) yang dijadikan sebagai strategi keunggulan daya saing (Porter, 1985). Halfert (1991) menyatakan bahwa Kinerja Organisasi adalah hasil dari semua laporan manajemen yang dilakukan secara terus menerus. Zeller, Stanko, dan Cleverley (1997) menyatakan bahwa Kinerja Organisasi merupakan cerminan 
apakah organisasi telah berhasil atau belum dalam menjalankan usaha bisnisnya. Gitman (1998) bahwa secara umum kinerja perusahaan digunakan untuk mengukur dampak dari suatu strategi perusahaan. Menurut Jauch dan Glueck (1998) menyataan bahwa Kinerja Organisasi dapat dilihat dari aspek kuantitatif dan kualitatif. Aspek kuantitatif membandingkan antara prestasi yang dicapai dengan kinerja sebelumnya atau dibandingkan dengan pesaing, seperti laba bersih, pertumbuhan penjualan dan juga tingkat efisiensi. Untuk pengukuran kinerja kualitatif berupa suatu pertanyaan yang diajukan apakah tujuan, strategi dan rencana terpadu. Menurut Whelen dan Hunger (2012) Kinerja Organisasi paling banyak diukur melalui Return on Investment (ROI) yang merupakan hasil bagi pendapatan sebelum pajak dengan total asset.

Studi ini merupakan penelitian eksplonatori yang bertujuan untuk menjelaskan hubungan variabel penelitian. Studi ini tidak langsung menghasilkan solusi untuk sebuah masalah atau problem (Zigmund, 2003:7). Subjek dalam studi ini berdasarkan pertimbangan kesesuaian dengan model penelitian. Lebih singkat studi ini tidak bertujuan untuk menyelesaikan permasalahan secara spesifik yang di hadapai oleh Industri UMKM Batik di Jawa Timur. Tetapi secara langsung mencoba mengembangkan sebuah teori berkaitan dengan hubungan Entreprenuerial Orientation, Culture Organization, Internal Factor, terhadap Performance Organization. Adapun studi ini fokus pada variabel intervening yaitu corporate Entreprenuership Capability. Hal ini melengkapi penelitian sebelumnya yang berkaitan dengan faktor-faktor yang dapat mempengaruhi Performance Marketing.

Penelitian ini selain penting untuk pengembangan teori di bidang ilmu pemasaran juga sangat penting peranannya sebagai salah satu upaya untuk meningkatkan kinerja organisasi pada Industri pada UMKM Batik di Jawa Timur yang selama ini masih banyak menghadapi berbagai permasalahan salah satunya adalah masalah sumberdaya manusia, teknologi dan pemasaran. Peningkatkan kinerja organisasi sangat diharapkan pada Industri UMKM Batik dan sangat penting bagi peningkatkan kesejahteraan masyarakat di Jawa Timur. Hal ini karena kontribusi Industri UMKM Batik di Jatim terhadap perekonomian sangat besar dan mampu menyerap tenaga kerja yang banyak. Berdasarkan perbedaan antara peneliti dengan penelitian terdahulu, yaitu menggunakan empat variabel yang meliputi :Entreprenuerial Orientation (EO), Culture Organization (CO), Internal Factor (IF) berpengaruh terhadap Performance Organization (PO) sedangkan pada penelitian ini menggunakan variabel Corporate Entreprenuership Capability (CEC) sebagai variabel intervening yang didasarkan pada konsep pemasaran dari Covin dan Slevin (1991), Ferdinand (2000), Ajzen (1991), Barney (1991) yang belum pernah diuji. Hal ini dilakukan peneliti karena peneliti ingin mengetahui faktor apa yang sebenarnya mempengaruhi performance organization di Industri Batik Tulis di Kota dan Kabupaten Jawa Timur. Mengingat ketidakjelasan dan semakin turunnya performance organization pada Industri Batik di Kota Jawa Timur.

\section{Rumusan Masalah}

1. Apakah Entreprenurial Orientation berpengaruh terhadap Corporate Entreprenurship Capability pada UMKM Batik di Jawa Timur?

2. Apakah Culture Organization berpengaruh terhadap Corporate Entreprenurship Cabability pada UMKM Batik di Jawa Timur?

3. Apakah Internal Factor berpengaruh terhadap Corporate Entreprenurship Capability pada UMKM Batik di Jawa Timur?

4. Apakah Entreprenuerial Orientation berpengaruh terhadap performance organization pada UMKM Batik di Jawa Timur?

5. Apakah Internal Factor berpengaruh terhadap performance organization pada UMKM Batik di Jawa Timur?

6. Apakah Corporate Entreprenurship Capability berpengaruh terhadap performance organization pada UMKM Batik di Jawa Timur?

7. Apakah Entreprenuerial Orientation berpengaruh terhadap Performance Organization melalui Corporate Entreprenuership Capability pada UMKM Batik di Jawa Timur?

8. Apakah Culture Organization berpengaruh terhadap Performance Organization melalui Corporate Entreprenuership Capability pada UMKM Batik di Jawa Timur?

9. Apakah Internal Factor berpengaruh terhadap Performance Organization melalui Corporate Entreprenuership Capability pada UMKM Batik di Jawa Timur? 


\section{Tujuan Penelitian}

Tujuan yang ingin dicapai dalam penelitian ini adalah memberikan pemahaman tentang kontroversi konseptual mengenai hubungan Coorporate Entreprenuerial Capability dan Performance Organization, serta untuk menelusuri dan menganalisis proses pengembangan entreprenurial orientation, culture organisasi, Internal factor. Disamping itu penelitian ini untuk menelusuri dan menganalisis proses pengembangan. Disamping itu penelitian ini diharapkan dapat memberikan penjelasan tentang proses transformasi entreprenurial orientation, culture organisasi, Internal factor berpengaruh terhadap performance organization yang selama ini dipandang belum jelas oleh para peneliti sebelumnya dengan cara memasukan variabel intervening yang menjembatani hubungan antara Corporate Entreprenuerial Capability dengan Performance Organization

\section{Kajian Pustaka dan Pengembangan Hipotesis} Landasan Teori

Theory of Planned Behavior (TPB) Menurut Covin dan Slevin (1991) "A Conceptual Model of Entrepreneurship as Firm Behavior" adalah penelitian generasi awal tentang entrepreneurship dipahami bukan lagi sebagai fenomena individual namun sebagai fenomena organisasi dan bahkan entrepreneurship sebagai perilaku organisasi. Morris, Kuratko dan Covin (2008:11) menjelaskan Corporate Entrepreneurship Capability adalah istilah dalam fenomena organisasi yang mendeskripsikan perilaku entrepreneurial di dalam organisasi skala menengah dan besar yang telah mapan Menurut Barney (1991)

Resource Based View (RBV) atau Resource Based Theory (RBT) menyebut sumber daya menjadi sumber daya unggulan bersaing dan kinerja yang berkelanjutan tersebut harus memenuhi beberapa kriteria "VRIN" yaitu valuable, rare, imperfect imitability/inimitable, dan nonsubstitutability. Sumber daya yang "valuable" artinya bahwa sumber daya tersebut berharga bagi oganisasi. Suatu sumber daya yang "rare" artinya bahwa sumber daya tersebut bersifat langka, jarang, dan unik.

Entrepreneurial orientation (EO) adalah membangun yang telah menarik dari kegiatan penelitian. Umumnya penelitian ini menemukan dukungan untuk hubungan yang positif antara semua dimensi (termasuk mengambil risiko EO) dan berhubungan dengan kinerja. Temuan kami menyarankan bahwa pernyataan mungkin dinyatakan signifikan. Dalam beberapa penelitian, Orientasi kewirausahaan mempunyai hubungan mungkin benarbenar kebalikannya. Hal ini menunjukkan bahwa penelitian yang berhubungan dengan EO akan dapat memberikan perhatian lebih pada konteks organisasi. Hubungan antara EO dan Kinerja Organisasi yang paling menarik perhatian para peneliti. Banyak Penelitian di bidang ini, kuatnya kinerja organisasi dianggap sebagai variabel dependen dan kegiatan entrepreneurship pada perusahaan-perusahaan dianggap sebagai variabel independen. Secara konseptual, ada konsensus yang kuat di antara peneliti tentang fakta bahwa hasil akhir kegiatan wirausaha adalah dapat peningkatan kinerja organisasi. Para peneliti berpendapat bahwa semakin tinggi orientasi kewirausahaan dapat mempengaruhi nilai yang kuat pula pada kinerja organisasi (Wiklund dan Gembala, 2005; Wiklund,1999; Pearce dan Carland, 1996; Zahra dan Covin, 1995; Zahra, 1991).

Menurut Robbins (1998: 248) mendifinisikan bahwa Budaya Organisasi adalah sebuah sistem pemaknaan bersama dibentuk oleh anggota organisasi yang sekaligus menjadi pembeda dengan organisasi lainnya. Menurut Morris, Kuratko dan Covin (2008) mengatakn bahwa Budaya Organisasi yang entrepreneurial adalah tipe Budaya Organisasi yang dapat mempengaruhi intensitas entrepreneurship dalam perusahaan. Budaya Organisasi menanamkan nilai, simbol, kosakata, mitos, aturan main dan metodologi pada perusahaan.

Husein Umar (2003: 74) bahwa faktor internal merupakan aspek-aspekyang ada di dalam perusahaan. Faktor internal dikaji melalui beberapa pendekatan, yaitu: pendekatan fungsional, pendekatan rantai nilai (value chain), kurva belajar/pengalaman (learning curve), core competence, dan balanced scorecard. Pendekatan fungsional mengategorisasikan analisis internal ke dalam pasar dan pemasaran, kondisi keuangan dan akunting, produksi, sumber daya manusia, dan struktur organisasi dan manajemen. Pendekatan rantai nilai dikembangkan oleh Porter dan didasarkan pada serangkaian kegiatan yang berurutan dari sekumpulan aktivitas nilai yang dilaksanakan untuk mendesain, memproduksi, memasarkan, 
mengirimkan serta mendukung produk dan jasa mereka pada perusahaan yang terdiri atas satu SBU.

Guth dan Ginsberg (1990) menekankan bahwa Corporate Entrepreneurship Cability mencakup dua fenomena utama: penciptaan bisnis baru dalam organisasi yang ada dan transformasi dari organisasi melalui pembaharuan strategi. Penelitian lainnya Damanpour (1991) menjelaskan bahwa Corporate Entrepreneurship Capability fokus pada memberi tenaga kembali dan mempertinggi kemampuan organisasi untuk mendapatkan keahlian dan kapabilitas inovasi. Sebuah inovasi dapat berupa produk dan pelayanan baru, sebuah sistem administratif atau perencanaan baruatau program baru yang bersinggungan dengan anggota organisasi. Menurut Halfert (1991) menyatakan bahwa Kinerja Organisasi adalah hasil dari semua laporan manajemen yang dilakukan secara terus menerus. Zeller, Stanko, dan Cleverley (1997) menyatakan bahwa Kinerja Organisasi merupakan cerminan apakah organisasi telah berhasil atau belum dalam menjalankan usaha bisnisnya. Slanjutnya menurut Gitman (1998) bahwa secara umum kinerja perusahaan digunakan untuk mengukur dampak dari suatu strategi perusahaan. Tetapi Menurut Jauch dan Glueck (1999) menyataan bahwa Kinerja Organisasi dapat dilihat dari aspek kuantitatif dan kualitatif. Aspek kuantitatif membandingkan antara prestasi yang dicapai dengan kinerja sebelumnya atau dibandingkan dengan pesaing, seperti laba bersih, pertumbuhan penjualan dan juga tingkat efisiensi. Untuk pengukuran kinerja kualitatif berupa suatu pertanyaan yang diajukan apakah tujuan, strategi dan rencana terpadu.

\section{Kerangka Proses Berpikir}

Kerangka proses berpikir dimaksudkan untuk memberikan tuntunan berpikir deduktif, menganalisis permasalahan penelitian dari hal-hal yang bersifat umum ke arah hal-hal yang bersifat khusus, untuk memperjelas wawasan dalam melakukan analisis melalui teori dan konsep yang telah mapan. Di samping itu juga memberikan tuntunan induktif, menganalisis permasalahan penelitian dari hal-hal yang bersifat khusus ke arah hal-hal yang bersifat umum untuk memperjelas wawasan dalam melakukan analisis melalui studi empiris. Studi ini menjelaskan hubungan Enterprenuerial Orientation, Culture Organization, Internal Factor mempengaruhi terhadap
Performance Organization melalui Corporate Entrepreneurship Dengan pendekatan deduktif dan induktif yang saling berhubungan, maka disusunlah hipotesis penelitian. Hipotesis penelitian merupakan jawaban sementara atas rumusan masalah yang perlu dikaji kebenarannya melalui uji statistik Partial Least Square. Berdasarkan pengujian hipotesis dihasilkan konsep disertasi secara menyeluruh dan diharapkan menghasilkan temuan teoritis, baik mendukung maupun menolak suatu teori yang telah ada, dan atau pengembangan suatu teori.
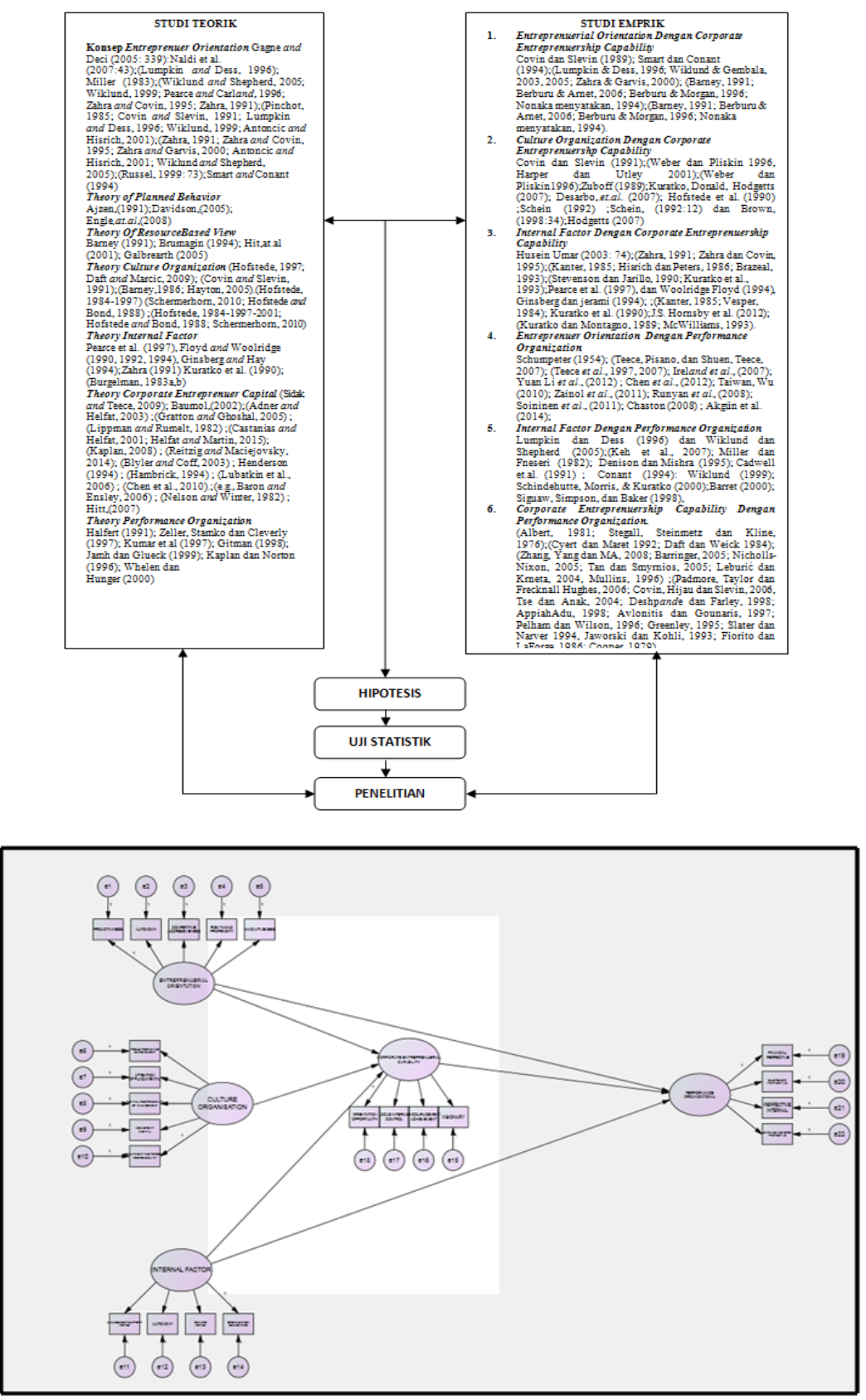


\section{Hipotesis Penelitian}

Berdasarkan atas landasan kerangka proses berfikir, kerangka teori dan kerangka konseptual penelitian, maka disusun hipotesis sebagai berikut :

\begin{tabular}{|c|c|}
\hline $\mathrm{H} 1$ & $\begin{array}{l}\text { : Entreprenurial Orientation } \\
\text { signifikan } \quad \text { terpengaruh }\end{array}$ \\
\hline & $\begin{array}{l}\text { Entreprenurship Capability Pada UMKM } \\
\text { Batik di Jawa Timur }\end{array}$ \\
\hline $\mathrm{H} 2$ & $\begin{array}{lcr}: \quad \text { Culture } & \text { Organization } & \text { berpengaruh } \\
\text { signifikan } & \text { terhadap } & \text { Corporate }\end{array}$ \\
\hline & $\begin{array}{l}\text { Entreprenurship Cabability Pada UMKM } \\
\text { Batik di Jawa Timur }\end{array}$ \\
\hline $\mathrm{H} 3$ & $\begin{array}{ll}\text { : Internal Factor berpengaruh signifkan } \\
\text { terhadap } \quad \text { Corporate Entreprenurship }\end{array}$ \\
\hline $\mathrm{H} 4$ & $\begin{array}{l}\text { Capability Pada UMKM Batik di Jawa Timur } \\
: \text { Entreprenuerial Orientation berpengaruh } \\
\text { signifikan terhadap performance organization } \\
\text { Pada UMKM Batik di Jawa Timur }\end{array}$ \\
\hline H5 & $\begin{array}{l}\text { : Internal Factor berpengaruh signifikan } \\
\text { terhadap performance organization Pada } \\
\text { UMKM Batik di Jawa Timur }\end{array}$ \\
\hline H6 & $\begin{array}{lcr}\text { : Corporate } & \text { Entreprenurship } & \text { Capability } \\
\text { berpengaruh } & \text { signifikan } & \text { terhadap }\end{array}$ \\
\hline & $\begin{array}{l}\text { performance organization Pada UMKM } \\
\text { Batik di Jawa Timur }\end{array}$ \\
\hline H7 & $\begin{array}{l}\text { : Entreprenuerial Orientation berpengaruh } \\
\text { positif terhadap Performance Organization } \\
\text { melalui Corporate Entreprenuership }\end{array}$ \\
\hline & Capability Pada UMKM Batik di Jawa Timur \\
\hline H8 & $\begin{array}{l}\text { : Culture Organization berpengaruh positif } \\
\text { terhadap Performance Organization melalui } \\
\text { Corporate Entreprenuership Capability Pada } \\
\text { UMKM Batik di Jawa Timur }\end{array}$ \\
\hline H9 & : Internal Factor berpengaruh positif terhadap \\
\hline & Performance Organization melalui Corporate \\
\hline & $\begin{array}{l}\text { Entreprenuership Capability Pada UMKM } \\
\text { Batik di Jawa Timur }\end{array}$ \\
\hline
\end{tabular}

\section{Metode Penelitian}

\section{Rancangan Penelitian}

Penelitian sosial pada umumnya terbagi atas tiga tipe penelitian, yaitu penelitian eksploratif (explorative research), deskriptif (descriptive research) dan penelitian eksplanatori (explanatory research). Studi ini termasuk kategori dalam penelitian eksplanatori, karena dalam studi ini dijelaskan hubungan atau pengaruh antar variabel yang diteliti. Masalah dalam penelitian eksplanatori berpusat pada keterhubungan antar variabel yang diteliti. Ditinjau dari tujuan penelitian, studi ini merupakan penelitian pengaruh karena berusaha menjelaskan pengaruh antar variabel-variabel yang terlibat dalam penelitian.

\section{Populasi Dan Sampel}

Populasi merupakan objek utama penelitian yang direncanakan. Hal ini sesuai dengan pendapat Sakaran (2005: 6), populasi merupakan semua nilai yang dihasilkan dari pengukuran secara kuantitatif maupun kualitatif dari karakteristik tertentu mengenai sekumpulan objek yang lengkap dan jelas yang ingin dipelajari. Menurut Ridwan \& Kuncoro,( 2008 : 37) mengatakan bahwa Populasi merupakan wilayah generalisasi yang terdiri dari objek, subjek yang menjadi kuantitas dan karakteristik tertentu yang ditetapkan oleh peneliti untuk dipelajari dan kemudian ditarik kesimpulannya. Populasi penelitian ini adalah semua industri UMKM Batik yang ada di Jawa Timur dan jumlah populasi adalah 30.261 (Sumber : Dinas Koperasi dan UMKM, 2016) baik industri skala mikro kecil maupun skala menengah UMKM Batik di Jatim.

Sampel dalam penelitian ini adalah Managemen tingkat midle atau manajer tingkat tengah sebagai responden di Perusahaan UMKM batik di Jawa Timur. Dengan alasan mengapa peneliti mengambil Sampel pada Manajer Tingkat Tengah dengan banyak pertimbangan karena orang tersebut yang mengetahui arah kerja dan kebijakan serta orang yang bertanggung jawab atas seluruh aktivitas perusahaan UMKM Batik tersebut di Jawa Timur. Adapun kriteria sampel pada perusahaan UMKM Batik di Jawa Timur sebagai berikut : Para Manajemen Tingkat Midle atau Manajer tingkat tengah pada UMKM Batik di Jawa Timur yang menjadi responden adalah yang sudah bekerja lebih dari 3 Tahun dan pernah memimpin lebih dari 3 Tahun juga. Dikarenakan dapat mengetahui kinerja organisasi secara keseluruhan dengan wawasan yang kuat pula dan lebih berpengalaman dalam menentukan kebijakan organisasi serta dapat mengetahui ukuran kinerja seluruh aktivitas organisasinya. Teknik Pengambilan Sample menurut Hair et al., (1995:637) mengatakan jumlah sampel yang ideal untuk SEM adalah antara 100-200 sehingga ukuran sampel minimum adalah sebanyak 5-10 observasi untuk setiap indikator. Ukuran sampel ditentukan berdasarkan metode Maximum Likelihood (ML) sesuai syarat minimal menurut (Hair et al., 1998:311; Ferdinand, 2000:43; 2002:48) yaitu ukuran sampel (data penelitian) yang 
sesuai untuk kebutuhan analisis SEM adalah berjumlah antara 100 sampai dengan 200. Penelitian ini menetapkan jumlah responden yang digunakan ada 200 responden, yang berarti asumsi untuk ukuran sampel telah terpenuhi.

\section{Klasifikasi Variabel}

Variabel adalah sesuatu yang mempunyai variasi nilai atau memiliki bermacam-macam nilai (Kerlinger, 1946 : 49) ; Singarimbun dan Effendi (1995 : 42) atau variabel sebagai segala sesuatu yang menjadi obyek pengamatan penelitian. Klasifikasi variabel didasarkan atas studi teoritik dan empirik secagai acuan kerangka berpikir deduktif, selanjutnya melalui studi empirik digunakan sebagai dasar untuk mengambil kesimpulan induktif, Pedhazur (1986) dalam singarimbun dan effendi (1995: 43). variabel yang digunakan dalam penelitian ini meliputi variabel bebas, variabel tergantung dan variabel intervening.

KLASIFIKASI VARIABEL PENELITIAN

\begin{tabular}{|c|c|c|c|}
\hline NOTASI & NAMA VARIABEL & $\begin{array}{l}\text { KLASIFIKASI } \\
\text { VARIABEL }\end{array}$ & INDIKATOR \\
\hline $\mathrm{X}_{1}$ & Entreprenuerial Orinetas & Bebas/Independen & $\begin{array}{l}E O 1=\text { Proaktivenne } \\
E O 2=\text { Autonomy } \\
E O 3=\text { Competitive aggresiveness } \\
\text { EO4 }=\text { Risk Taking Propensity } \\
\text { EO5 }=\text { Innovatiness }\end{array}$ \\
\hline $\mathrm{X}_{2}$ & Culture Organization & Bebas/Idependen & $\begin{array}{l}\mathrm{CO} 1=\text { Focus On Peaple andempowerment } \\
\mathrm{CO} 2=\text { Attention to Basics } \\
\mathrm{CO} 3=\text { Hands On Management } \\
\mathrm{CO} 4=\text { Freedom to Grow and To Fail } \\
\mathrm{CO} 5=\text { Commitment and personality } \\
\text { Responssibility. }\end{array}$ \\
\hline $\mathrm{X}_{3}$ & Internal Factor & Bebas/Idependen & $\begin{array}{l}\text { IF1 }=\text { Managemennt Support For CEC } \\
\text { IF2 }=\text { Autonomy } \\
\text { IF3 }=\text { Reward For CEC } \\
\text { IF4 }=\text { Organization Boundaries }\end{array}$ \\
\hline $\mathrm{Y}_{1}$ & $\begin{array}{l}\text { Performance Marketing } \\
\text { Orientation }\end{array}$ & Terikat/Dependen & $\begin{array}{l}\text { Financial Perfective } \\
\text { Customers Pervective } \\
\text { Internal Bussiness Prepective } \\
\text { Learning and Growth Prevective }\end{array}$ \\
\hline $\mathrm{Y}_{2}$ & $\begin{array}{l}\text { Corporate Entreprenuer } \\
\text { Capability }\end{array}$ & $\begin{array}{l}\text { Moderasi// } \\
\text { Intervening }\end{array}$ & $\begin{array}{ll}\text { CEC1 } & \text { = Vision } \\
\text { CEC2 } & \text { = Drive to achieve } \\
\text { CEC3 } & =\text { Intemal locus of } \\
& \text { control } \\
& \text { = Opportunity } \\
\text { CEC4 } & \text { oventation } \\
& \text { =Creativity \& Innovation } \\
\text { CEC5 } & =\text { Calculated risk taking } \\
\text { CEC6 } & \end{array}$ \\
\hline
\end{tabular}

\section{Pengukuran Variabel}

Dalam penelitian ini menggunakan skala pengukuran yang digunakan untuk mengukur factorfaktor yang mempengaruhi Entreprenurial Orientation, Culture Organization, Internal factor terhadap performance organization, melalui entreprenurship capability pada Industri UKM Batik Tulis Di Jawa Timur adalah skala interval. Skala interval adalah skala yang menunjukan jarak antara satu data dengan data yang lain dan mempunyai bobot yang sama. Skala sikap yang digunakan adalah Likert Scale atau ( Skala Likert), Ridwan \& Kuncoro ( 2008 : 68). Skala likert digunakan untuk mengukur sikap, pendapat dan persepsi seseorang atau sekelompok tentang kejadian. Variabel ini dijabarkan atau di artikan menjadi indicator-indikator yang dapat diukur. Indicator yang terukur dijadikan titik tolak untuk membuat item instrument yang berupa peryataan yang perlu dijawab oleh responden. Setiap item yang dimasukkan telah memenuhi uji empiris mengenai kemampuan membedakannya. Skala dalam penelitian ini mudah digunakan dalam penelitian yang berfokus terhadap responden. Setiap jawaban dihubungkan dengan bentuk peryataan atau dukungan sikap yang merupakan gradasi dari sangat positif sampai sangat negatif dengan kriteria skor $1-5$.

\section{Metode Pengumpulan Data}

Sebelum menemukan hasil penelitian ataupun mengelola data, tahapan penting dalam Penelitian Kuantitatif adalah menentukan teknik pengumpulan data. Sugiyono (2013:194) mengemukakan terdapat tiga pengumpulan data berdasarkan tekniknya yaitu wawancara, angket (kuisoner), dan observasi. Dalam penelitian ini menggunakan metode penelitian antara lain : Survei pendahuluan dengan dilakukan pada perusahaan UMKM Batik Tulis yang sudah ditentukan dan dengan melakukan wawacara langsung dengan pihak -pihak manajemen yang terkait pada perusahaan UMKM Batik Tulis di Jatim untuk memperoleh gambaran umum dengan keadaan perusahaan yang ada di masing-masing kota di Jatim serta segala aktifitasnya. Selanjutnya melakukan penelitian lapangan. Penelitian lapangan dilakukan dengan membagikan angket pada para pimpinan perusahaan pemilik industri Batik di masing-masing kota sebagai responden agar peneliti dapat lebih mengetahui permasalahan secara empiris. Selanjutnya peneliti melakukan metode wawancara lalu peniliti melakukan metode Studi literature untuk memperoleh data secara teoris dengan cara membaca dan mempelajari buku-bukuyang berhubungan dengan masalah yang diteliti.

\section{Teknik Analisi Data}

Teknik analisis yang akan digunakan dalam penelitian ini adalah memakai analisis SEM. Data dianalisis dengan menggunakan SEM (Structural Equation Modeling) program AMOS (Arbukle, 1997: 18; serta Ferdinand, 2002: 48) untuk memberikan gambaran yang jelas hubungan antara konstruk penelitian. Model persamaan struktural dari AMOS dipakai untuk memperoleh indikator-indikator model yang fit. Alasan menggunakan metode Structural 
Equation Modelling (SEM) adalah karena teknik multivariat ini yang menggabungkan aspek dari regresi berganda (meneliti hubungan ketergantungan) dan analisis faktor untuk mengestimasi rangkaian hubungan ketergantungan yang saling berhubungan secara simultan (Hair et. al., 1999, p. 621). Permodelan penelitian melalui SEM memungkinkan seorang peneliti dapat menjawab pertanyaan penelitian yang bersifat regresif maupun dimensional (yaitu mengukur apa dimensi-dimensi dari sebuah konsep).

Pada saat seorang peneliti menghadapi pertanyaan penelitian berupa identifikasi dimensidimensi sebuah konsep atau kostruk (seperti yang biasanya dilakukan dalam analisis faktor) dan pada saat yang sama peneliti ingin mengukur pengaruh atau tingkat hubungan antar faktor yang telah diidentifikasikan dimensi-dimensinya itu SEM akan merupakan alternatif jawaban yang layak dipertimbangkan. Oleh karena itu dapat dikatakan bahwa pada dasarnya SEM adalah kombinasi antara analisis faktor dan analisis regresi berganda (Ferdinand, 2002, p. 7). Tolok ukur yang digunakan dalam menguji masing-masing hipotesis satu sampai dengan lima adalah nilai CR (Critical Ratio) pada Regression Weights dengan nilai minimum dua secara absolut. Muller (1996: 23) dan Ferdinand (2002: 34) menyatakan bahwa penggunaan SEM terdiri 7 tahap proses yaitu :

- Mengembangkan model berdasarkan teori.

- Membentuk diagram alur (path diagram) dari hubungan kausal.

- Mengubah diagram alur (path diagram) ke dalam persamaan struktural dan model pengukuran.

- Memilih tipe matrik input dan estimasi model yang diajukan.

- Menilai identifikasi dari model struktural

- Mengevaluasi kriteria kesesuaian model (Goodness-of Fit) Interpretasi dan modifikasi Model

\section{Hasil dan Pembahasan}

Penelitian ini menghasilkan suatu output yang sangat signifikan dalam meningkatkan performance organisasi yang diukur dengan 4 perpektif antara lain financial, customer, business process, growh dan learning. Dari empat perfektif tersebut menghasilkan suatu nilai yang positif pada dimensi entrepreneurial orientation yang dapat mempengaruhi corporate entrepreneurship capability dengan baik terbukti bahwa mempunyai pengaruh yang kuat untuk meningkatkan kinerja organisasi dan dimensi culture organization menghasilkan nilai positif juga dalam meningkatkan performance organization melalui peningkatan corporate entrepreneurship capability. Serta internal factor juga mempengaruhi adanya peningkatan performance organization secara bersamasama maupun secara parsial internal factor ini mempunyai nilai yang dominan terhadap performance organization melalui pembenahan kemampuan kewirausahaan yang ada di UMKM batik Jatim, dengan melihat data yang bervariatif maka tidak sekedar pengetahuan saja tetapi harus kuat dalam peningkatan kemampuan agar dapat terbentuk karakter kewirausahaan yang kuat sehingga kinerja organisasi semakin meningkat pula. Penelitian ini didukung oleh Hasil penelitian terdahulu Wiechmann et al., (2003) \& Wiklund dan Shepherd (2005) mengidentifikasi hubungan positif antara orientasi kewirausahaan, budaya organisasi , faktor internal dan kinerja bisnis, demikian juga Wiklund (1999). Tetapi penelitian Frank et al., (2010) mengatakan orientasi kewirausahaan berpengaruh negatif terhadap kinerja bisnis. Demikian juga penelitian terdahulu menunjukan lemahnya hubungan antara orientasi kewirausahaan dengan kinerja perusahaan melalui kemampuan kewirausahaan perusahaan (Lumpkin dan Dess, 2001).

Keadaan ini tentu saja akan membawa pengaruh positif karena jika potensi batik ini di Jatim dapat terus ditingkatkan maka akan dapat menurunkan angka kemiskinan dan pengangguran di Indonesia. Peningkatan pasar dalam negeri serta jumlah Industri UMKM batik yang terus mengalami peningkatan ini perlu di respon serta memerlukan upaya dari segenap pihak agar pengembangan dan pemberdayaan Industri UMKM batik ini agar tepat sasaran. Peningkatan pasar dalam negeri tercermin dari peningkatan jumlah konsumen batik dalam negeri sebesar 72,86 juta orang pada Tahun 2011. Potensi ini akan menjadi salah satu kekuatan luar biasa di sektor industri kreatif jika digarap dengan serius. Pemerintah juga telah mencanangkan batik sebagai pakaian resmi nasional. Di instansi pemerintah dan swasta juga telah mewajibkan karyawannya untuk mengenakan batik pada hari atau acara tertentu sebagai bentuk semangat kebanggaan dan kesadaran untuk mempertahankan dan 
mengembangkan batik sebagai kebanggaan Indonesia. Hal ini merupakan peluang yang baik bagi Industri UMKM batik untuk terus berupaya meningkatkan kualitas produksinya serta kreasi inovasi motif batik sesuai dengan kekhasan daerah masing-masing di Indonesia. Berdasarkan data Kementerian Perdagangan Tahun 2015, menunjukkan potensi yang sangat besar pada UMKM batik yang terus mengalami peningkatan. Hal ini dapat dilihat bahwa terdapat peningkatan nilai transaksi total produk batik sebesar $56 \%$, yaitu sebesar 2,9 triliun di Tahun 2009 meningkat menjadi 3,9 triliun pada Tahun 2010. Selain itu perkembangan pasar dalam negeri telah mendorong jumlah UMKM batik di Indonesia terus bertumbuh dari 53.250 unit usaha pada Tahun 2009 dengan 873.510 tenaga kerja menjadi 55.778 unit usaha pada Tahun 2015 dengan mempekerjakan 916.783 tenaga kerja.

\section{Simpulan}

Berdasarkan hasil penelitian dan pembahasan mengenai pengaruh entrepreneur orientation, culture organization, internal factor terhadap performance melalui coorporate entreprenuership capability usaha batik yang berada di daerah Sentra UKM Batik Jatim, dapat ditarik kesimpulan sebagai berikut: 1. Orientasi Kewirausahaan sebagian besar pengusaha sentra sentra UKM Batik sudah tinggi. Bila dilihat berdasarkan indikator, tampak bahwa persentase skor tanggapan responden terhadap sebagian besar indikator termasuk dalam kategori sangat baik. Hanya indikator memperhatikan sesuatu cara yang tidak biasa, toleransi dan keterbukaan yang masih termasuk dalam kategori cukup hal ini dikarenakan para pengusaha masih belum terbuka untuk hal-hal yang besifat intern perusahaannya. 2. Budaya Organisasi yang sebagian besar pengusaha sentra sentra UKM Batik Tulis Jatim sudah baik. Bila dilihat berdasarkan indikator, tampak bahwa persentase skor tanggapan responden terhadap sebagian besar indikator termasuk dalam kategori sangat tinggi. 3. Internal factor pada UMKM Batik Tulis di Jatim sudah baik hanya saja perlu dikontrol dan diperhatikan 4. kinerja usaha yang sebagian besar usaha sentra sentra UKM Batik Jatim sudah cukup baik . Bila dilihat berdasarkan indikator, tampak bahwa persentase skor 100 tanggapan responden terhadap sebagian besar indikator termasuk dalam kategori baik. Hanya indikator waktu kerja yang termasuk dalam kategori sangat tinggi hal ini dikarenakan waktu kerja sangat penting karena pembutan batik secara manual sangat membutuhkan waktu yang cukup lama. 5. Kemampuan kewirausahaan pada perusahaan masih terbilang masih belum optimal berpengaruh signifikan terhadap pembentukan karakter kewirausahaan pada Sentra UKM Batik Jatim karena tanpa ada ketidakmampuan kewirausahaan maka tidak dapat terlaksanakan dengan baik. Jadi berdasarkan hasil pengujian dapat disimpulkan bahwa kreativitas secara parsial berpengaruh terhadap kinerja usaha pada Sentra UKM Batik Tulis Jatim Secara langsung faktor internal yang dapat memberikan pengaruh terhadap kinerja usaha melalui pembentukan kemampuan kewirausahaan pada perusahaan. Kemudian secara tidak langsung karena hubungannya dengan corporate entrepreneur capability memberikan pengaruh Jadi berdasarkan hasil pengujian dapat disimpulkan bahwa Orientation Kewirausahaan, Budaya Organisasi dan internal factor secara parsial berpengaruh terhadap kinerja usaha pada Sentra UKM Batik Jatim.

\section{Referensi}

[1] Adams, K., Grose, R., Leeson, D., \& Hamilton, H. (2003). Internal Control And Corporate Governance. Frenchs Forest, New South Wales, Australia: Pearson Education.

[2] Akgün \& T. and Kerr, S. (2014) The Boundaryless Organization: Breaking the Chains of Organizational Structure, Jossey-Bass, San Francisco, CA.

[3] Alejandro,et.al, (2008) The distributional Dynamic of income and comsumption: strategies firm performance, Journal of Marketing,Vol.2, 235-276.

[4] Albert, 1981; Stegall, Steinmetz dan Kline, (1976) \& Aaby, N., \& Slater, S. F. (1989). Management influences on export performance: A review of the empirical literature 1978-1988. International Marketing Review, 6(4), 7-26.

[5] Ajzen, I. (1991). The Theory of Planned Behavior . Organizational Behavior and Human Decision Processes 50, pp. 179-211.

[6] Anas .B , 1997 Indonesia Indah Batik, Pustaka Harapan Kita Jakarta

[7] Arikunto ( 2006) , Metode Penelitian Survey, Penerbit PT. Media Pustaka Indonesia. Jakarta.

[8] Astamoen, H. M. (2008). Entrpreneurship dalam Perspektif Kondisi Bangsa Indonesia. Bandung: Alfabeta. 
[9] Avlonitis and Salavou, 2007 Information system for small and medium sized enterprises, Journal of Business Research, 60 (2007) 566-575

[10]Azis, (1982) \& Riduwan \& Achjari (2004) Partial Least Square: Another Method of Structural Equatron Modeling Analysis. Journal Ekonomi dan Bisnis Indonesia, vol.-.

[11]Baker, W. E., and J. M. Sinkula, 1999, The Synergistic Effect of Market Orientation and Learning Orientation on Organizational Performance, Journal of the Academy of Marketing Science, Vol 27, 411-427

[12]Baker, W. E., Sinkula, J.M. (2002), "Market orientation, learning orientation and product innovation: delving into the organization's black box," Journal of Market Focused Management, $5,5-23$.

[13] Baker, W. E., Sinkula, J.M. (2005), "Market orientation and the new product paradox," Journal of Product and Innovation Management, 22(6), 483-502.

[14]Baker, William E., dan James M. Sinkula, 1999. "The Synergistic Effect of Market Oriented and Learning Organization on Organization Perfomance". Journal of The Academy Marketing Science. p. 411-427

[15]Barney, Jay, "Strategic factor markets: expectations, luck, and business strategy", Management Science, 1986, Vol. 32, No. 10, 1231-1241.

[16]Barney, Jay, "Firm Resources and Sustained Competitive Advantage", Journal Of Management, 1991, Vol. 17, No. 1, 99-120.

[17]Barney, Jay, "Is the resource-based "view" a useful perspective for strategic management research? Yes", Academy of Management Review, 2001, Vol. 26, No. 1, 41-56.

[18]Barney, 1991, Firm Resources and Sustained Competitive Advantage, Journal of Management. 17 :101; R. Hall, 1992 ; The Strategic Analysis of Intangible Resources Strategic Management Journal .13:135-144

[19] Barringer, B.R, and Bluedorn, A.C. (1999). The Relationship Between Corporate Entreprenueship And Strategic Management. Strategic Management Journal 20 : 421-444

[20] Barney, 1991; Barburu \& Arnet, 2006 \& Morgan, 1996; Nonaka,1994, Noteboom, 1994) Innovation and Diffusion in Small Firms: Theory and Evidence, Small Business Economics 6, 327347.

[21]Baum, Joel and Korn, Helaine, "Competitive dynamics of interfirm rivalry", Academy Of Management Journal, 1996, Vol. 39, No. 2, 255291.
[22]Bernheim, B. Douglas and Whinston, Michael, "Multimarket Contact and Collusive Behavior", The RAND Journal of Economics, 1990, Vol. 21, No. 1, 1-26.

[23] Bearden, 2005; Moncrieff, 1999; Moorman, 1995; Menon dan Varadarajan, 1993; Hari, 1991; Yohanes dan Martin, 1984; Hall, Hass dan Johanson, J., \& Mattsson, L.G. (1988). Internationalization in industrial systems - A network approach. In: N. Hood (Ed.), Strategies for Global Competition. London, UK: Croom Helm.

[24] Barburu, 1995 \& Morgan, 1996 Environment and strategy as antecedents for marketing effectiveness and organizational performance, Journal of Stratgeic Management 7 , p.237-250

[25] Barburu \& Morgan, 1996; Ireland et al., 2003; Shane \& Venkataraman, 2000) Fostering Entrepreneurship in the Large, Diversified Firm, Organisational Dynamics, 18 (1), 20-32

[26] Bartlett, C.A., Ghoshal, S., \& Barret (2000) Release the entrepreneurial hostages from your corporate hierarchy. Strategy Leadership 24 (2), 36-42 (July/August).

[27]Becherer, R.C. and Maurer, J.G. (1997) \& Siguaw, Simpson, dan Baker (1998), "The moderating effect of environmental variables on the entrepreneurial and marketing orientation of entrepreneur-led firms", Entrepreneurship Theory and Practice, Vol. 22 No. 1, pp. 47-58.

[28] Besanko, David, Dranove, David and Shanley, Mark, Economics of Strategy, 2000,USA, John Wiley \& Sons, Inc.

[29] Boeker, Warren, Goodstein, Jerry, Stephan, John and Murmann Johann Peter, "Competition in Multimarket Environment: The Case of Market Exit",Organization Science, 1997, Vol.8,No. 2, 126-142.

[30] Berthon, P., Hulbert, J., Pitt, L. (1999), "To serve or to create? Strategic orientations towards customers and innovation,"California Management Review, 42(1), 37-58.

[31]Besanko, David, Dranove, David and Shanley, Mark, Economics of Strategy, 2000, USA, John Wiley \& Sons, Inc.

[32] Baum, Joel and Korn, Helaine, "Competitive dynamics of interfirm rivalry", Academy of Management Journal, 1996, Vol. 39, No. 2, 255291.

[33] Burgelman dan Sayles, 1986) A Process Model of Internal Corporate Venturing in the Diversified Major Firm, Administrative Science Quarterly, 28, 223-244.

[34] Burgelman, R.A., \& Hitt, M. (1991). Entrepreneurial Action, Innovation and 
Appropriability. Strategic Entrepreneurship Journal, 1:349-352.

[35] Bowman, Cliff, “'Value' in the ResourceBased View of the Firm: A Contribution to The Debate", Academy of Management Review, 2001, Vol. 26, No. 4, 501-502

[36] Bozic, L. (2006), "The effects of market orientation on product innovation," Economic Trends and Economic Policy, 107, 46-65. Burgelman, R., Christensen, C., Wheelwright, S.C., Maidique, M.A., Strategic Management of Technology and Innovation. McGraw Hill Irwin, Boston, MA, 2004.

[37] Calantone, Roger J, Benedetto, C. Anthony dan Bhoovaraghavan, Sriraman, 1994. "Examining the Relationship between Degree of Innovation and New Product Success", Journal of Business Research, p. 143 - 148.

[38] Carland, J.W., Hoy, F., Boulton, W.R. and Carland, J.A.C. (1984); Loane, Bell, and Cunningham (2009) "Differentiating entrepreneurs from small business owners: a conceptualization", Academy of Management Review, Vol. 9 No. 2, pp. 354-9.

[39] Castro et al, 2005; Kirca et al, 2005; Jain dan Bhutia, (2007); Why do firms cooperate on $R \& D$ ? An empirical study, Research Policy, Vol. 21, pp. 347-360

[40] Ciputra. (2009). Ciputra Quantum Leap. Jakarta: PT Elex Media Komputindo.

[41] Craven, David W, 1996. "Pemasaran Strategis", Jilid 1, Suatu Terjemahan, Erlangga, Jakarta.

[42] Conner, Kathleen, "A Historical Comparison of Resource-Based Theory and Five Schools of Thought Within Industrial Organization Economics: Do We Have a New Theory of the Firm?", Journal of Management, 1991, vol. 17, No. 1, 121-154.

[43] Coff, Russell, “When Competitive Advantage Doesn't Lead to Performance: The Resource Based View and Stakeholder Bargaining Power”, Organization Science, 1999, Vol. 10, No. 2, 119-133.

[44]Cohen, Wesley and Levinthal, Daniel, "Absorptive Capacity: A New Perspective On Learning And Innovation”, Administrative Science Quarterly, March 1990, Vol. 35, No. 1, 128-152.

[45]Collis, David, "A Resource-Based Analysis of Global Competition: The Case of the Bearings Industry”, Strategic Management Journal, 1991, Vol. 12, Special Issue, 49-68.

[46] Chaudhary et al. (2012) Contingent labor as an enabler of entrepreneurial growth. Human Resource Management Journal, 42(4), 357-373
[47] Chaston (2008) \& Carland, J.W., Hoy, F., Boulton, W.R. and Carland, J.A.C. (1984) "Differentiating entrepreneurs from small business owners: a conceptualization", Academy of Management Review, Vol. 9 No. 2, pp. 354-9.

[48]Chen, 1996 Absorptive competitor analysis and interfirm, Administrative Science Quarterly, Vol. 35 No.1, pp.128-52

[49] Chen, Ming Jer, "Competitive analysis and interfirm rivalry: Toward a theoretical integration”, Academy of Management Review, 1996, Vol. 21, No. 1, 100-134.

[50]Chi, Tailan, "Trading in Strategic Resources: Necessary Conditions, Transaction Cost Problems, and Choice of Exchange Structure”, Strategic Management Journal, 1994, Vol. 15, No. 4, 271-290.

[51]Chrisman (1999) "Measuring the performance of emerging businesses: a validation study”, Journal of Business Venturing, Vol. 8 No. 5, pp. 391-408

[52] Chow \& Sherry E.S. (2006) Customer Service, Entrepreneurial Orientation, and Performance: A Study in Helath Care Organizations in Hongkong, Italy, New Zealand, the United Kingdom, and the USA. Journal of Applied Management and Entrepreneurship, Vol. 11 No. 4, 2006, pp. 33-48

[53] Coulthard,( 2007) Organizational Commitment in Mexican Small and Medium-Sized Firms: The Role of Work Status, Organizational Climate, and Entrepreneurial Orientation. Journal of Small Business Management, Vol 45 Nol 4, 2007, pp. 467-490.

[54] Cooper, Donald R. \& C. William Emory, 1999, Metode Penelitian Bisnis, Edisi kelima, Erlangga, Jakarta

[55] Cooper , Robert G., 2000. "Product Innovation and Technology Strategy", Journal Research Technology Management, p. 38 -41.

[56] Covin and slevin and miller et.al , 2005, Entreprenuerial orientation and business performance, Entreprenuership Theory and Practice, in Press

[57] Covin and slevin and miller et.al , 2008, Entreprenuerial orientation and business performance, Entreprenuership Theory and Practice, in Press, Version 2

[58]Covin dan Slevin (1991), Ferdinand (2000) , Ajzen (1991), Barney (1991) Competitive Aggressiveness, Environmental Context, and Small Firm Performance, Entrepreneurship: Theory and Practice, Volume $14,35-51$

[59] Covin dan Slevin \& Lumpkin, G. T. and Dess, G. G. (1996). Clarifying the entrepreneurial 
orientation construct and linking it to perfomance. Academy of Management Review 12(1), pp. 135-72.

[60] Damanpour, F., 1991. \& Desarbo et al. (2005) Organizational innovation: a meta-analysis of effects of determinant and moderators. Acad. Manage. J. 34, 55-390.

[61] Damanpour (1991) Time and entrepreneurial risk behavior. Entrepreneurship Theory Pract. 22, 69-88.

[62] Drucker, P. (1985). The Discipline of Innovation. Harvard Business School Publishing Corporation.

[63] Fast, N. D.,\&Pratt, S. E. (1981). \& Frank (2010) Individual entrepreneurship and the large corporation. In: K. H.Vesper (Ed.), Frontiers of Entrepreneurship Research (pp. 443 450).Wellesley, MA: Babson College.

[64]Ferdinand, A. (2002). Structural Equation Modeling dalam Penelitian Manajemen: Aplikasi Model-Model Rumit dalam Penelitian Untuk Tesis, Magister dan Disertasi Doktor, Edisi II. Semarang: Universitas Diponegoro.

[65]Ferdinand, A. (2005). Structural Equation Modeling dalam Penelitian Manajemen: Aplikasi Model-Model Rumit dalam Penelitian Untuk Tesis, Magister Semarang: Universitas Diponegoro.

[66]Ferdinand, A. (2012 ). Structural Equation Modeling dalam Penelitian Manajemen: Aplikasi Model-Model Rumit dalam Penelitian Untuk Tesis, Magister Semarang: Universitas Diponegoro. ( New Revisi)

[67]Ferdinand, A.T., 2000, Manajemen Pemasaran : Sebuah Pendekatan Stratejik, Badan Penerbit Universitas Diponegoro

[68] Ferdinand, Augusty, 2000b. "Structural Equation Modeling Dalam Penelitian Manajemen". Seri Pustaka Kunci No. 02 Semarang : Program Magister Manajemen Universitas Diponegoro (Agustus)

[69] Ferdinand, A.T., 2003, Suistanable Competitive Advantage : Sebuah Eksplorasi Model Konseptual, Badan Penerbit Universitas Diponegoro

[70]Ferdinand, A.T., 2004, Strategic Selling-In Management : Sebuah Pendekatan

[71] Feifei Yu (2012) Fast, N. D.,\& Pratt, S. E. (1981) \& Feifei Yu (2012) Individual entrepreneurship and the large corporation. In: K. H.Vesper (Ed.), Frontiers of Entrepreneurship Research (pp. 443-450).Wellesley, MA: Babson College.

[72]Fielden dan Davidson (2005) Davidsson, P. (2004). Researching Entrepreneurship. New York: Springer Science.
[73] Floyd, S. W., \& Woolridge, B. (1999) \& Frishamar dan Horte (2007) Knowledge creation and social networks in corporate entrepreneurship: The renewal of organizational capability.Entrepreneurship Theoryand Practice, 23(3), 123-143.

[74] Floyd, S.W., 1990 \& Weber dan Pliskin 1996 \& Harper \& Utley 2001. The strategy process, middle management involvement, and organizational performance. Strategic Manager. J. 11, 231-241.

[75] Frishammar dan Horte 2007; Becherer dan Maurer,( 1997) The Entreprenuerin The Market Orientation at University of Twente Student, Journal of Business Research, ISRN:LTEX-72, p. 252.56 ref.

[76] Galbreath, Jeremy. 2005. Which resources matter the most to firm succes? An exploratory study of resource-based theory. Technovation 25 (2005) 979-987

[77] Galbraith dan Kzanjian, dalam Eric, 2005 A critical look at the technological innovation typology and innovativeness terminology: a literature review, The Journal of Product Innovation Management, Vol. 19, pp. 110-132.

[78] Gitman, L. (1998). Corporations; Business Enterprises; Finance. Addison Wesly.

[79] Gitman and Jauch and Glueck (1999), Business Policy and Strategic Mangement, Book Company, New York, 1988.

[80] Gozalli, 2011, Metodologi Penelitian, Cetakan ke empat, Jakarta , Ghalia Indonesia

[81] Guth dan Ginsberg (1991), Covin dan Slevin (1991) Covin J.G., And Slevin, D.P., 1991, A Conceptual Model of Entrepreneurship as Firm Behavior, Entrepreneurship Theory and Practice, 16, 7-25

[82] Hadi (1989) \& Sunyoto (2008) Metodologi Reseacrh Jilid I \& II, Penerbit Andi Offset Yogjakarta.

[83]Hanan, M., 1976 \& Hashim et al., (2001) Venturing corporations - think small to stay strong.Harv. Bus. Rev. 54, 139-148.

[84]Hansen, E. L., \& Witkowski, T. H. (1995) \& Hasim (2011) Entrepreneur involvement in international marketing: The effects of overseas social networks and selfimposed barriers to action. In: G. E. Hill et al. (Eds), Research at the Marketing/Entrepreneurship Interface (pp. 363367). Chicago, IL: University of Illinois at Chicago.

[85] Http : dispkompumkm,jatimprov.go.id

[86] Halfert and Zeller, Stanko, and Cleverley (1997) The relationship betwen credit \Characteristic and microenterprise performance, Journal of 
Management Development, Vol.18, No.2 Emerald, 9 Januari 1997.

[87] Hair , Joseph F. JR., Rolph E. Anderson, Ronald L. Tatham, William C. Black, 1995. "Multivariate Data Analysis With Readings", 4th Edition, Prentice Hall, New Jersey.

[88] Hasan (2002 ) Metode Riset untuk Bisnis dan Ekonomi, Penerbit Cahaya Murni Jakarta

[89]Heinonem and Poikkijoki,(2006) Corporate entrepreneurship. Strategic Manage. J. 11, 5-15 (special issue)

[90] Helm Jones, C., Hesterly,W. S., \& Borgatti, S. P. \& Mj. Sheepers \& J.Hough \& JZ.Bloom, (2008) A general theory of network governance: Exchange conditions and social mechanism and corporate entreprenuership capability and firm performance. Academyof Management Review, 22(4), 911-945.

[91]Hughes dan Morgan (2007) Hughes, P., Morgan, R.E. and Kouropalatis, Y."Market knowledge diffusion and business performance". European Journal of Marketing, Vol. 42, issue 11/12, pp. 137295.

[92] Hodgetts, (2007), Blended Leaning in Entreprenuership Education in The Asia Pasific, Public administration Wiley online libary version of record 3 April 2007.

[93] Hofstede G, Neujen B., Ohayv D.D, \& Sanders G. (1990). Measuring Organizational Cultures. A Hornsby J.S, Kuratko D.E, \& Zahra S.A. (2002). Middle manager's Perception of the Internal Environment for Corporate Entrepreneurship: Assesing a measurement scale. Journal of Business Venturing, 17(3), 253-273.

[94] Hitt M.A, \& Keats De Marie. (2011). Academy of Management Executive: The Thingking Manager New. NY: Academic of Management.

[95] Isa, 2007 “ Peran ekonomi dalam meningkatkan perkembangan usaha mikro kecil dan menengah "Pres-Conference Tingkat Nasional di Jakarta

[96] Ireland, R. D., Hitt, M. A., Camp, S. M., \& Sexton, D. L. (2001, vol 15. No. 1). Integrating entrepreneurship and strategic management actions to create firm wealth. Academy of Management Executive, pp. 49 - 63.

[97] Ireland, R.D., \& Hitt, M. (1999). Achieving and Maintaining Strategic Competitiveness in the 21st Century: The Rote Strategic Leadership. In Academy of Management Executive (pp. 13 (1), 43-57).

[98] Ireland, R.D., Hitt, \& Hoskisson. (1995). Strategic Management Competiveness and Globalization Concepts. St. Paul MN: West Publishing Company.
[99] Ireland, R.D., Covin, J.G., Kuratko, D.F. (2009). Conceptualizing Corporate Entrepreneurship Strategy, Entrepreneurship Theory and Practice.

[100] Indriantoro dan Supomo, (1999) Metode Riset untuk Bisnis dan Ekonomi, Penerbit Erlangga Jakartaa.

[101] Indrianto. Et.al, (1999:29) , Metodologi Penelitian Bisnis Untuk Kalangan Akademisi, USU international Repository, Universitas Sumatra Utara. Edisi satu.

[102] Indrianto dan Supomo, (1999:P.115) MetodologiPenelitian, Edisi Pertama, Penerbit BPFE Yogyakarta

[103] Jauch dan Glueck (1999) Manajemen Strategis dan Kebijakan Perusahaan. Jiménez \& Sanz Valle, (2011) \& Jiménez-Jiménez, D. and Cegarra-Navarro, J.G. (2007) Theperformance effect of organizational learning and market orientation. Industrial Marketing Management 36, 694-708

[104] Kanter, 1985; Hisrich and Peters, 1986; Brazeal, 1993 Organizational Change and Sociology Perpective, Journal of Business \& Economic, Vol.4 Page. 436.

[105] Kara,(2005), The effect of a market orientation on Business Performance : A Study of Small Sized Service Retailers Using MARKOR Scale, Journal Business of Reseach Academic, nomer ISSN: 7026597-603 Vo. 29, Issue.10,pg.101-122.

[106] Kuratko,(2008) Corporate Entreprenuership Capability \& Innovation, Strategy Entreprenurship : Exploring Different Perpectives of an Emerging Concept, Journal of Strategic Managemnet, Version of Record 29 Des 2008, Vo.18, pg. 201-208.

[107] Kanter, 1985 dan Vesper, 1984 Corporate entreprenuership capability and middle manage : a model for corporate entreprenurial behavior, Journal of Business Venturing, Vol.25, pg, 13-17,

[108] Karim (2007) Corporate entreprenuership and entreprenuerial orientation in corporate performance, Journal of Management Studies, 46 (2) 308-335Kaplan, R. (1992, January February). The Balance Scorecard - Measure that Drive Performance. Harvard Business Review, pp. 71-79.

[109] Kaplan, R. S., \& Norton, D. P. (1992, January Pebruary). The Balanced Scorecard Measure that drive performance. Harvard Business Review, pp. 71-79.

[110] Karim. (2007). Analisis Pengaruh Kewirausahaan Korporasi terhadap Kinerja Perusahaan pada Pabrik Pengolahan CRUM 
RUBBER di Palembang. Manajemen \& Bisnis Sriwijaya, vol.5, no.9.

[111] Knight, G.A. (1997), “Cross-cultural reliability and validity of a scale to measure firm entrepreneurial orientation and firm performance", Journal of Business Venturing Vol. $\quad 12$ No. 3, pp. 213-25.

[112] Kellinger, 1993 Metode Riset untuk Bisnis dan Ekonomi, Penerbit Pustaka Leba Yogjakarta.

[113] Kuncoro, Mudrajat 2003, Metode Riset untuk Bisnis dan Ekonomi, Erlangga, Jakarta

[114] Mac. Millian et al., 1986; Sathe, 1985, 1989; Sykes, 1986; Sykes dan memblokir, 1989; Burgelman, 1983a,b, 1984; Quinn, 1985; Kanter, 1985; Ellis dan Taylor, 1988; Walker O.C. Jr., And Ruekert, R.W., 1987) Marketing's Role in the Implementation of Business Strategies: A Critical Review and Conceptual Framework, Journal of Marketing 45, 15-33.

[115] Madhani, (2009), analisis pengaruh intelectual capital teerhadap kinerja perusahaan sektor farmasi yang terdaftar di bursa efek indonesiaJurnal Undip.

[116] Miller, 1983; Lumpkin dan Dess, 2001; Wiklund, 1999; Wiklund \& Gembala, 2005; Zahra \& Covin, 1995; Zahra \& Garvis, 2000) Predictors and Financial Outcomes of Corporate Entrepreneurship: An Exploratory Study. Journal of Business Venturing , (July) : 259-285

[117] Miller (1983). The Correlates of Entrepreneurship in Three Types of Firms. Management Science, Vol.29 No. 7, pp. 770-91.

[118] Miller (1983), Stevenson dan Jarrilo (1990), Covin dan Slevin (1991), dan Hussey (1997) The Innovative Challenge. New York, Wiley,

[119] Min \& Chung, (2010), Entrepreneurship Correlates, in Three Types of Firms, Management Science, 29, 770-794

[120] Minztberg, 1979 The Structuring of Organizations: A Synthesis of the research, Journal of Business, ISBN: 9780138552701

[121] Morris, Kuratko, Covin (2008), Kuratko, D.F., Montagno, R.V., Hornsby, J.S., 1990, Developing, an Entrepreneurial Assessment Instrument for an Effective Corporate Entrepreneurial Environment, Strategic Management Journal, 11, 49-58.

[122] Morris, M. H., Kuratko, D. F., \& Covin, J. G. (2008). Corporate Entrepreneurship \& Innovation. USA: Thomson South-Western

[123] Morris, M. H. (2003). Entrepreneurship as a Significant Factor in Societal Quality of Life. Journal of Business Research, 13, 1:21-36.
[124] Morris, M. H. (2008). Corporate Entrepreneurship \& Innovation. Second Edition, Thompson South Western.

[125] Morris, M. H., Kuratko, D. F., \& Covin, J. G. (2008). Corporate Entrepreneurship \& Innovation. USA: Thomson SouthWestern.

[126] Morris, M. H., Sexton, D. \& Lewis, P. (1993). (n.d.). Entrepreneurship, Growth and Quality of Life ; Implications For Public Policy. Journal of Private Enterprise, 9, 1 (summer), 24 - 58.

[127] Morris, Kuratko dan Covin (2008) Estimating Effect Size from prettest conrol group designs organization research and corporate entrepreneurship capability, Journal Academic Research Institutute, Vol.3.pg. 11-17.

[128] Nadler, D.A. and Tushman, M.L. (1997) \& Newbert (2008), Competing by Design: The Power of Organizational Architecture, Oxford University Press, New York, NY.

[129] Naldi et al. (2007) A Strategic Fit Perfective on Family firm performance

[130] Nazir, (2005) Metode Penelitian, Penerbit Erlangga-Jakarta

[131] Narver, J. C., \& Slater, S. F. 1990. "The Effect of Market Orientation on Business Profitability", Journal of Marketing. Pp.20 35.

[132] Narver, Jhon C,. dan Slater, F Stanley 1994. Does Competitive Environment moderate the Market Orientation-Performance Relationship ?.Journal of Marketing. 58:45-55

[133] Narver, J., Slater, S., 1994, Market Orientation, Customer Value, and Superior Performance, Business Horizons, March-April

[134] Narver, J. C., \& Slater , S. F. 1995. "Market Orientation and The Learning Organization ”, Journal of Marketing. p.63 - 74.

[135] Narver, Jhon C,. dan Slater, F Stanley,2000. The Positive Effect Of A Market Orientation on Business Profitaility:A Balance Replication. Journal Of Business Research,69-73

[136] Narver, J., Slater, S., 2000, Intelligence Generation and Superior Customer Value, Academy of Marketing Science Journal. Greenvale: Winter 2000. Vol. 28, Iss. 1; pg. 120,8 pgs

[137] Navarro, A., Acedo, F.J., Robson, M.J., Ruzo, E., and Losada, F., 2010a, "Antecedents and consequences of firms export commitment: An empirical study”. Journal of International Marketing, Vol. 17 issue 3, pp. 1-33.

[138] Navarro, A., Losada, F., Ruzo, E. and Diez, J.A., 2010b, "Implications of perceived 
competitive advantages, adaptation of marketing tactics and export commitment on export performance". Journal of World Business, Vol. 45, issue 1, pp. 49-58

[139] Nunnally, J.C., 1978, Psychometric Theory. McGraw-Hill. New York, NY.

[140] Noe et al., 2006; Ainuddin et al., 2007; dan Nasution et al., 2011, The Customer Experince Frame Work as Baseline for Strategy and Implementation in Service Marketing, Journal Science Marketing, Vol. 2 no.1 , 345-367.

[141] O'Regan et al. (2008) Managing innovation: controlled chaos. Harv. Bus. Rev. 63, 73-84 (May/June).

[142] Peruci dan Hamby \& Tampubolon, (2004:184) “ Perilaku Organisasi “ Penertbit Ghalia Indonesia Jakarta.

[143] Pinchot, 1985; Covin dan Slevin, 1991; Lumpkin dan Dess, 1996; Wiklund, 1999; Antoncic dan Hisrich,R.D, 2001), Entrepreneurship: Starting, Developing, and Managing a New Enterprise, 4th ed., Irwin, Chicago, IL

[144] Porter, Michael E. (1985), Competitive Advantage. New York: The Free Press. Porter Michael, Competitive Strategy: Techniques for Analyzing Industries and Competitors, 1980, New York, The Free Press.

[145] Quinn, 1985; Hisrich dan Peters, 1986; MacMillian et al., 1986; Sykes dan memblokir, 1989; Sathe, 1989; Stevenson dan Jarillo, 1990; Damanpour, 1991; Kuratko et al., 1993; Pearceet al., 1997) Developing, an Entrepreneurial Assessment Instrument for an Effective Corporate Entrepreneurial Environment, Strategic Management Journal, 11, 49-58.

[146] Ridwan \& Kuncoro, 2008, Cara menggunakan dan menganalisis Analisis Jalur, Penerbit Alfabeta-Bandung

[147] Robert W. Duncan (2007, 142) Analisis Factor yang mempengaruhi kinerja pemasaran dalam dimensi lingkungan internal dan ekternal. Jurnal of Management,ISSN.2878-3548 Vol.1, hal. 142-146.

[148] Robbins, S.P. (2003). Organizational Behavior, Eleventh Edition. Singapore: Prentice Hall.

[149] Rusa (1992) \& Rose, C., \& Thomsen, S. (2004) The impact of corporate reputation on performance: Some Danish evidence. European Management Journal 22(2), pp. 201-210

[150] Russell, R.D. and Russell, C.J. (1992), “An examination of effects of organizational norms, organizational structure, and environmental uncertainty on entrepreneurial strategy",
Journal of Management, Vol. 18 No. 4, pp. 639-56.

[151] Russell, R.D. (1999), “Developing a process model of intrapreneurial systems: a cognitive mapping approach”, Entrepreneurship Theory and Practice, Vol. 23 No. 3, pp. 65-84.

[152] Sangen,2005 Pengaruh orientasi pasar, inovasi dan orientasi pembelajaran terhadap kinerja perusahaan unit mikro, kecil dan menengah, Jurnal Management, Vol. 28, hal. 176-179.

[153] Sakaran,U.(2005) Research methods for business: A skill building approach (4th.ed) New York : Jhon wiley \& Sons,Inc.

[154] Selnes et al, 1996; Pelham, 1997; Harris, 2001; Deshpanhe et al, 2000 Market Orientation and Other Potential Influences on Performance in Small and Medium-Sized Manufacturing Firms, Journal of Small Business Management, S.4867.

[155] Singarimbun, M. (1995). Metode Penelitian Survey, Cetakan Kedua. Jakarta: LP3ES.

[156] Siswadi \& Robbins \& Sembiring (2012) Pengaruh Motivasi kerja dan kepemimpinan dan Budaya organisasi, Jurnal ISSN. 12838584, Vol.1, hal. 122-126.

[157] Sittimalakorn dan Hart, 2004 Market OrientationVersus Quality Orientation : Sucess of Superior Business Performance, Journal of Strategic Management, ISSN.12243-253, Desember 2014

[158] Sugiyono (2003) Metodologi Penelitian Ekonomi , Penerbit Cahaya Pustaka Yogjakarta

[159] Sugiono, (2009) Metode Riset untuk Bisnis dan Ekonomi, Penerbit Cahaya Pustaka Yogjakarta.

[160] Susanto, A. (1997). Budaya Perusahaan. Seri Manajemen dan Persaingan.

[161] Scanlan, 1981; Souder,1981; Kanter, 1985; Sathe, 1985; Menggoreng, 1987; Blok dan Ornati, 1987; Sykes, 1992; Barringer dan Milkovich, 1998) The Role of Entrepreneurial Orientation on Firm Performance and the Potential Influence of relational Dynamism. Journal of global Business and Technology, Vol. 3 No. 1, 2007, pp. 29-39.

[162] Schein (2004), Organization Culture and driver of competitive advantange. Journal Academic research Institutute, Vol.2, 37.p. 230-240

[163] Schepper J Hough \& J.Z. Bloom, (1998) Encouraging entrepreneurship in large corporations. Res. Manage. 24 (3), 18-22 (May)

[164] Schumpeter, J. A. (1936). The Theory of Economic Development. Cambridge University Press, Cambridge, U.K. 
[165] Schumpeter, J. A. (1942). Capitalism, socialism, and democracy. New York: Harper \& Row.

[166] Schumpeter, J. A. (1950). Capitalism, Socialism, and Democracy (3rd edn). Harper \& Row,New York.

[167] Schumpeter, J. A. (1911). Theorie der wirtschaftlichen Entwicklung. Munich and Leipzigh: Dunker and Hamblat.

[168] Schollhammer, H. (1982) \& Smart dan Conant (1994), "Internal corporate entrepreneurship", in Kent, C.A., Sexton, D.L. and Vesper, K.H. (Eds), Encyclopedia of Entrepreneurship, Prentice-Hall, Englewood Cliffs, NJ, pp. 20929.

[169] Sveiby, K.E. (1997) \& Sharma dan Chrisman (1999), The New Organizational Wealth: Managing and Measuring Knowledge-based Assets, Berrett-Koehler Publishers, San Francisco, CA.

[170] Suci, 2008; Tan dan Tan, 2005, Technological innovation, entrepreneurship, and strategy. Sloan Manage. Rev. 20 (3), 19-30.

[171] Souder, 1981; Sathe, 1985; Hisrich dan Peters, 1986; Sykes, 1986; Sykes dan blokir, 1989; Burgelman dan Sayles, 1986; Schuler, 1986; Burung, 1988; Guth dan Ginsberg, 1990; Covin dan Slevin, 1991; Zahra, 1991, 1993; Brazeal, 1993; Hornsby et al., 1993) Strategic Consensus and Performance: The Role of Strategy Type and Market-Related Dynamism, Strategic Management Journal, 20, s.356357Timmons, J.A (2000). New Venture Creation. Homewood, IL: Irwin Publishing

[172] Teece et al., (1997) \& Tsai, W. and Ghoshal, S. (1998), "Social capital and value creation: the role of intrafirm networks", Academy of Management Journal, Vol. 41 No. 4, pp. 46476.

[173] Taylor dan Frecknall Hughes, 2006; Covin, Hijau dan Slevin, 2006, Tse dan Anak, 2004; Deshpande dan Farley, 1998; AppiahAdu, 1998; Avlonitis dan Gounaris 1997; Pelhamdan Wilson, 1996; Greenley, 1995; Slater dan Narver 1994,Jaworski dan Kohli, 1993; Fiorito dan LaForge, 1986; Cooper, 1979) Business Research Methods, fifth ed. Richard D. Irwin, Homewood, IL.

[174] Umar, 1999, Metode Riset untuk Bisnis dan Ekonomi, Penerbit Cahaya Murni Yogjakarta.

[175] Udan Bintaro \& Uzzi, B.(2002) Social structure and competition in interfirm networks: The paradox of embeddedness. Administrative Science Quarterly, 42, 35-67.

[176] Von Hippel, 1977; Souder, 1981; Kanter, 1985; Sathe, 1985; Sykes,1986; Sykes dan memblokir, 1989; Hisrich dan Peters, 1986; Katz dan Gartner, 1988; Stopford dan Baden Fuller, 1994; Das dan Teng, 1997; Slevin dan Covin, 1997. Entrepreneurial Strategy making and Firm Performance: Test of Contingency and Configurational Models. Strategic Management Journal, Vol. 18 No. 9, 1997, pp. 677-696.

[177] Von Hippel, E., (1977 ) \& Ginn dan Young (1992), Sriram (1996), dan Veliyath et al. (1994) Successful and failing internal corporate ventures: an empirical analysis. Ind. Mark. Manage. 6, 163-174.

[178] Weber \& Pliskin1996 \& Thurik, R. 1999), "Linking entrepreneurship and economic growth", Small Business Economics, Vol. 13 No. 1, pp. 27-55.

[179] Whelen dan Hunger (2012) Strategic Management and Bussiness Policy and Achieving Sustainability, Management Book W.432012-658-4012-dc22. Pg145.

[180] Weber and Pliskin 1996 Antecedents to Employee Re Commitment after Acquisition; Corporate cultural fit and perfomance in mergers and acquisition. Journal Of Strategic Management, Vol. 25, pg, 23-28, Pres.

[181] Wiechmann, D., Ryan, A. M., \& Hemingway, M. (2003) \& Wiklund dan Shepherd (2005). Designing and implementing global staffing systems: Part I - Leaders in global staffing. Human Resource Management, 42(1), 71-83.

[182] Wiklund, 1999; Wiklund \& Shepherd, 2003; Lumpkin et al., 2005; Li et al., 2008; Madhous et al., 2011; Home, 2010; dan Nasution et al. 2010, Entrepreneurial Orientation and Business Performance an Assessment of past reseach and suggestions for the future, Jounal Entheprenuership Theory and Practice, in press; Journal Marketing, Vol. 1 No. 2 Page 234-245.

[183] Wolcott, R., \& Lippitz, M. (2007). The Four Models of Corporate Entrepreneurship. vol.49 no.1.

[184] Zahra (2000) and Fitzgerald E M, ( 2002), Antoncic (2004), Corporate entreprenuerial contigencies and organizational wealth creation, Journal of Management Development,Vol.23, No.6 Emerald.

[185] Zulfadil, 2014, Kapability seorang entrepreneur (wirausaha), Jurnal Usahawan No.10 Tahun 'XXXVI

[186] Zahra, 1991 dan Covin, 1995 The effect Organizational Culture on Corporate Entreprenuership and Corporate entreprenuership capability for firm 
performance, Journal of Business Venturing, 1995,Number : 43-58,19951781,1995.

[187] Zahra, A.S., \& Garvis, D. (1998). International Corporate Entrepreneurship and Firm Performance: The Moderating Effect of International Environment Hostility.Academy of Management Best Paper's Proceedings, (pp. 1-24).

[188] Zeller, T., Stanko, B., \& Cleverly, W. (1997). A New Perspective on Hospital Financial ratio Analysis. Journal of Healthcare Financial Management.

[189] Zigmund, 2003 Environment, Corporate Entrepreneurship and Financial Performance, A Taxonomic Approach, Journal of Business Venturing, $7: 17$

[190] Zuboff (1989) \& Zeller, T., Stanko, B., \& Cleverly, W. (1997). A New Perspective on Hospital Financial ratio Analysis. Journal of Healthcare Financial Management.

[191] Zhang, Yang dan MA, 2008; Barringer, 2005; Nicholls-Nixon, 2005; Tan dan Smyrnios, 2005; Leburić dan Krneta, 2004, Mullins, 1996 \& Misra, K. M., Singh, J. S., Cardon, M. S., \& Dewettenick, K. (2003). Performance, creativity and empowerment dynamics for front line employees in service organizations. American Marketing Association Meetings Proceedings. 